\title{
Effects of Using Solar Water Heating System on Fuelwood Consumption in Forest Villages
}

\author{
Günay ÇAKIR ${ }^{1 *}$. Süleyman Aykut TONYALI² \\ ${ }^{1}$ Gümüşhane University, Gumushane Vocational School, Department of Forestry, Gumushane, TURKEY \\ ${ }^{2}$ Forest Engineer, General Directorate of Forestry, Bolu Forest Directorate, Bolu, TURKEY \\ *Corresponding Author: cakirgunay@gmail.com
}

Received Date: 24.06.2020

Accepted Date: 16.03.2021

\section{Abstract}

Ain of study: In this study, the effects of the use of solar water heating system of forest villagers in Gumushane were investigated.

Material and methods: For this purpose, random selected by 70 forest village households were examined and the results were analyzed by One Sample T-Test. Within the scope of the research, face-toface surveys were conducted with the families with the villagers who were determined with information provided by Department of Forest-Village Relations. The villagers were chosen among those who had used this solar energy heating system for at least 5 years. The data in the questionnaires were transferred to digital media and it was tried to determine how the forest villagers were affected by solar water heating systems.

Main results: As a result, after the use of solar water heating systems; the consumption of firewood for heating has not changed. The consumption of wood used for cooking and the consumption of wood used for hot water has also decreased.

Highlights: Thanks to this solar water heating system, carbon accumulation in forests has increased and a positive contribution has been made to climate change.

Keywords: Forest villager, One sample T-test, Gumushane

\section{Orman Köylerinde Güneş Enerjili Su Isıtma Sistemi Kullanımının Yakacak Odun Tüketimi Üzerindeki Etkileri}

Öz

Çalışmanın amacı: Bu çalışmada, Gümüşhane'de orman köylülerinin güneş enerjili su 1sıttma sistemi kullanımının etkileri araştırılmıştır.

Materyal ve yöntem: Bu amaçla rastgele seçilen 70 orman köy hane halkı incelenmiş ve sonuçlar Tek Örnek T-testi ile analiz edilmiş̧ir. Köylüler güneş enerjili su 1sıtma sistemini en az 5 yıl kullananlar arasından seçilmiş̧ir. Araştırma kapsamında, Gümüşhane Orman İşletme Müdürlügü̈'nün Orman ve Köy İlişkileri Birimince verilen aile bilgisiyle aileler ile yüz yüze anketler yapılmıştır. Anketlerdeki veriler dijital ortama aktarılmış ve güneş enerjili su ısıtma sistemleri kullanan orman köylülerinin nasıl etkilendikleri belirlenmeye çalışılmıştır.

Temel sonuçlar: Sonuç olarak güneş enerjisi su isıtma sistemlerinin kullanımından sonra; 1sıtma amaçlı yakacak odun tüketimi değişmemiştir, yemek pişirmek için kullanılan odun tüketiminde ve sıcak su için kullanılan odun tüketimi de azalma olmuştur.

Araştırma vurguları: Bu sistem sayesinde ormanlarda karbon birikimi artmış ve iklim değiş̧ikliğine olumlu katk1 sağlanmıştır.

Anahtar kelimeler: Orman Köylüsü, Tek örnek t testi, Gümüşhane 


\section{Introduction}

Today, clean energy sources are great importance to our world. The rapid growth of the world population has caused an increase in energy needs. Increasing energy demands of the countries brought about environmental negative effects. Therefore, natural resources are constantly consumed to provide energy. Countries are divided into three classes as developed, semi-developed, and underdeveloped countries. Developed countries meet their energy needs nuclear, fossil fuels, hydrogen, wind, and solar energy. New ones can be added to these types of energy in the coming years. In semideveloped countries, energy resources are mostly provided by agricultural materials such as fossil fuels, wood, fertilizer and waste (İstanbullu, 1978; Çakır, 2013).

In some regions of Turkey, energy has been traditionally provided by wood, dung and agricultural wastes. Energy is one of the basic criteria for economic development. Today, it is aimed to provide energy sources from renewable and clean sources in forest villages. Alternative energy sources that can be used instead of firewood should be provided to the villagers. It is important to make more use of solar energy and to diversify it because it does not create environmental threatening questions and is clean and environmentally friendly. In this context, acceptable researches and pioneering studies are carried out in developed countries. These countries plan to generate $20 \%$ of their energy needs from solar energy in the future (DPT, 2006; EIGM, 2014).

The cycle of development has been arising from the desire of societies to grow and the expansion cycle in nature has revealed to be effective in our lives. When there is not enough energy or resources both growth and weak energy resources will begin to decrease (Odum \& Odum, 2006). Although nature always follows the rules of the universe, people try to play the game by their own rules (Pham, et al., 2020).

The need for energy increases by $5 \%$ every year in the world where is obtained from fossil fuels. Today, the global climate has directed effected to human beings to clean and renewable energy sources. Turkey is a poor country in terms of fossil energy sources.
Therefore, it imports about $72 \%$ of its energy. for the closure of Turkey's deficit should be directed to renewable energy sources. When we look at renewable energy sources, solar energy comes first. Turkey, its location is located in an area known as the solar generation. As the number of sunny days is high, it is country rich in solar energy (Doğan, 2012; Altuntop \& Erdemir, 2013).

In Law No. 2924 supporting the development of forest villagers is referred within or adjacent to forest area. Forest villages have scattered settlements due to the difficult conditions in terms of land where their lands are fragmented, small, inefficient and unsuitable for agriculture. Forest villagers are generally in the low-income group and benefit from the services and investments of the state very little (GDF, 2018). The forest villagers use wood for sheltering, cooking and heating in the region. It consists of degradation of ecology which is the destruction of wildlife habitat, erosion, climate change, severe floods, reduction and pollution of groundwater, etc. This is generally obtained from fossil fuels.

Today, global politics has beings to clean and renewable energy sources since 1990 (EIGM, 2014). The main reason for the consumption of wood raw material in forest villages as fuel for heating and feeding purposes is the poor economic situation of the families living there. The main idea of the project for the development of forest villagers has been improving the economic conditions of forest villages by using a solar water heating system where was a surge in the economic situation of these rural families (Türker \& Toksoy, 1992). The amount of energy use by 2017 in Turkey respectively; coal (44\%), hydroelectric dams and systems (22\%), wind (19\%), natural gas (17\%), geothermal (4\%), and others (4\%). Use of Turkey's renewable energy sources in 2019; hydroelectric is $64 \%$, solar energy $13 \%$, wind energy 17\%, geothermal 3\% and bioenergy $2 \%$. (IRENA, 2020). The sources that have the biggest share are fossil fuels. The solar energy and water heating type project of General Directorate of Forestry and Village Relations (ORKOY), which is one of the social projects, is found successful by all subjects. The ORKOY officials interviewed stated that the 
solar energy and water heating type project, which was realized by making revision changes in the development plan, was a correct project for the region and they expect a decrease in wood consumption. The forest villagers have expressed their satisfaction despite the short time passed. It has been found that solar heating systems have a significant effect on the use of firewood by forest villagers. In light of the information obtained from the studies carried out in various years, it is seen that a household saves an average of 5 ster and approximately 1750 $\mathrm{kg}$ of firewood per year (GDF, 2014).

Another goal of this solar water heating system is to reduce forest villagers' use of wood for heating and cooking. The stove is designed to heat the living spaces as well as to cook and to maintain the temperature of the water. The stoves distributed by ORKOY caused significant decreases in the amount of firewood consumption, but could not eliminate the dependence on firewood. Between 1992 and 1994, 9 thousand families were provided with stove loans (Çoban, 1997; ORKOY, 2014; TUIK, 2014).

\section{Material and Methods \\ Study Area}

Gumushane is located in the North Eastern region in Turkey. Geographic location is approximately between $38^{\circ} 40^{\prime}-40^{\circ} 10^{\prime}$ east longitudes and 39 $50^{\prime}-40^{\circ} 60^{\prime}$ northern latitudes (Figure 1).

Gumushane has a surface area of $6575 \mathrm{~km}^{2}$ and an average altitude of $1210 \mathrm{~m}$. In this direction, the defining feature of the northern part is the high mountains separated by narrow and deep valleys and the famous highlands are found in this region. Abdal Musa Hill is the highest peak of the province with $3331 \mathrm{~m}$ about sea level (GGv, 2014).

The average number of open and sunny days in Gumushane is 79 and the average number of closed sunny days is 68 . Spring and winter months are rainy, winters are generally snow-shaped and spring is rainy. When the meteorological statistics are considered, the average annual temperature is $4.3^{\circ} \mathrm{C}$. The average temperature is the highest in August with $20.4{ }^{\circ} \mathrm{C}$ and the lowest in January with $1.6^{\circ} \mathrm{C}$. between 1961 and 2018, the lowest temperature was $-25.7^{\circ} \mathrm{C}$ in February and the highest temperature was $41.1^{\circ} \mathrm{C}$ in August (MGM, 2014).

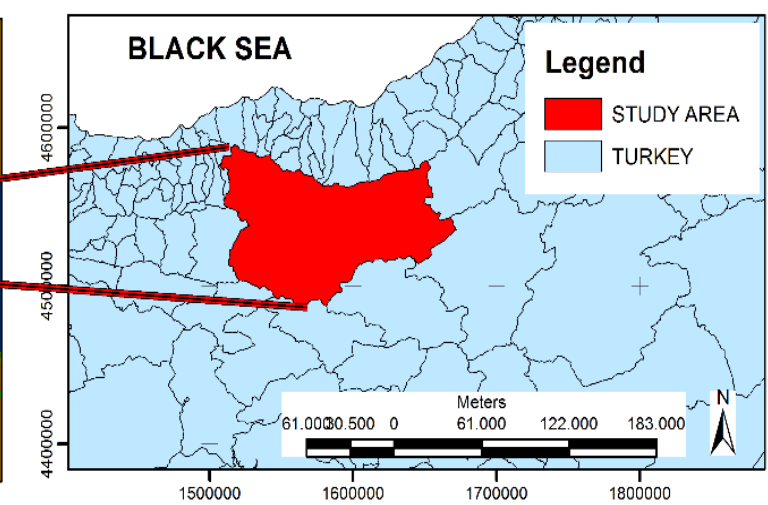

Figure 1. Study area

\section{Data Collecting}

This study was conducted to determine the socio-economic situation provided by the use of solar water heating system in forest villages that it was carried out in two stages. The first stage consists of obtaining the data from public institutions and the second stage consists of surveys with families using solar water heating systems. Required approval was obtained by the Gumushane University
Scientific Research and Publication Ethics Committee for the surveys. Data were obtained by subjecting the questionnaires to statistical analysis.

At least 3 families from each forest village were randomly selected from the list of families receiving solar energy from the Gumushane Forestry Operation Directorate. This number had been increased to 5 in villages where the solar energy system is over- 
distributed. The number of surveys generally corresponds to $1 / 3$ of the number of forest village households distributed.

In addition, surveys were conducted on more families from villages where this system is widely given. The data on the amount of firewood given to forest villagers and the number of villages and units where solar energy systems projects are applied were obtained from the ORKOY branch of Gumushane Forest Management Directorate. 70 households were selected by random sampling from forest villages in Gumushane province. 37 families who did not want to answer the questionnaires are worried about that there will be problems in the future as a result of their answers. The villagers were chosen among those who have used this solar energy heating system for at least 5 years.

During the research, some forest villagers did not want to respond to the surveys. In society, a structure was bored from answering questionnaire that questions were observed and stayed away. We stated that the study would be beneficial for the village people and we sought answers to our surveys. Between 2011 and 2013, a 21 forest villages (Ikisu, Inözü, Gökçeler, Gökdere, Aktutan, Mescitli, Dörtkonak, Konacık, İnkılap, Çevrepınar, Çamur, Evren, Sökmen, Sadak, Kılıçtaşı, Babakonağı, Bezendi, Boğazyayla, Kızılcaköy, Çaltılı and Subaşı) had been established 257 units of solar water heating system (Table 1). In the research, transactions were made over the forest villagers who participated in the questionnaires. Those who did not answer the questionnaire were not evaluated. A face-to-face interview with 70 of these villagers were conducted (Tonyal,, 2019).

Questionnaires were formed by examining the related researches. The questions in the questionnaire applied are aimed at collecting information about the demographic, educational and economic conditions of the subjects, their relations with households, their opinions about the loans granted by this institution and forestry activities.

Table 1. Field survey number of households in forest villages

\begin{tabular}{|c|c|c|c|}
\hline Forest village name & $\begin{array}{l}\text { Population } \\
\text { (TUIK's data) }\end{array}$ & $\begin{array}{l}\text { Number of } \\
\text { Households Survey }\end{array}$ & $\begin{array}{l}\text { Number of Household No } \\
\text { comment/survey }\end{array}$ \\
\hline Aktutan* & 366 & 2 & 1 \\
\hline Babakonağ $1 * *$ & 540 & 2 & 3 \\
\hline Bezendi $* *$ & 392 & 4 & 1 \\
\hline Boğazyayla*** & 144 & 4 & 1 \\
\hline Çamur** & 503 & 5 & 1 \\
\hline Çaltılı* & 43 & 2 & 3 \\
\hline Çevrepınar*** & 160 & 4 & - \\
\hline Dörtkonak* & 335 & 5 & 1 \\
\hline Evren*** & 288 & 4 & 2 \\
\hline Gökçeler*** & 363 & 5 & 1 \\
\hline Gökdere* & 115 & 4 & 2 \\
\hline İkisu $*$ & 141 & 2 & 3 \\
\hline İnk1lap**** & 299 & 3 & 3 \\
\hline İnözü*** & 88 & 3 & 2 \\
\hline Kizılcaköy** & 333 & 3 & 2 \\
\hline Kılıçtaş1** & 351 & 3 & 3 \\
\hline Konac1k****** & 172 & 5 & 1 \\
\hline Mescitli* & 169 & 2 & 3 \\
\hline Sadak** & 1013 & 5 & - \\
\hline Sökmen** & 426 & 2 & 2 \\
\hline Subaş1***** & 247 & 1 & 2 \\
\hline Total & & 70 & 37 \\
\hline
\end{tabular}


Taking into account the size of the universe $p$ (probability of the sample mass to be measured in the main mass) and q values were calculated. 70 samples using solar energy heating system from forest villagers in Gumushane province were searched for answers to the following three hypotheses.

Hypothesis 1: Does the solar energy heating system have an effect on the consumption of heating firewood? $\mathrm{H}_{10}$ : The consumption of firewood did not change after the use of solar energy. $\mathrm{H}_{11}$ : The consumption of firewood changed after the use of solar energy.

Hypothesis 2: Does the solar energy heating system have an impact on the consumption of firewood in cooking? $\mathrm{H}_{20}$ : The consumption of firewood did not change after the use of solar energy. $\mathrm{H}_{21}$ : Consumption of firewood changed after use of solar energy.

Hypothesis 3: Does the solar energy heating system have an effect on the consumption of firewood in water heating? $\mathrm{H}_{30}$ : The consumption of firewood did not change after the use of solar energy $\mathrm{H}_{31}$ : Consumption of firewood changed after use of solar energy. The answers given by forest villagers in the environment of the hypotheses determined were subjected to statistical analysis and the results were obtained accordingly.

\section{Results}

\section{Socio-Demographic Results}

This study has been prepared to determine the satisfaction of forest villagers who have installed a solar water heating system where was installed by ORKOY in 2011 for the forest villagers subject to the survey. As a result of face-to-face interviews with forest villagers, the results of this project were evaluated according to three hypotheses. 96\% of those using ORKOY loans are male. Although this result indicates that women are not interested in ORKOY projects, this is due to the Turkish family structure. Because solar water heating type projects will benefit to women. $93 \%$ of the subjects are married. $64 \%$ of those using ORKOY loans are primary school graduates.

The level of education in forest villages is low. It is a known fact that there is a positive relationship between education level and welfare level. The low level of welfare adversely affects the education expenditures of forest villagers.

The youngest respondent was 24 years old and the oldest was 45 years old. Since most of the forest villagers migrated to big cities, fewer families received ORKOY loans. Loan use is higher in villages close to the city center. The main reason for this is that villagers have the opportunity to work in different jobs in the center, apart from the forestry activities in the village. $76 \%$ of the forest villagers using ORKOY loans are content to be forest villagers. The reason for this is the peaceful environment of the local village life and the emotional environment of the region.

The villagers who are not satisfied with being a forest villager are the reasons for dissatisfaction was low yields of forests, limited job opportunities, lack of social productivity, lack of social security and lowest of agricultural activities. Forest villages were found to be in good condition when taken in terms of freshwater. All of the subjects stated that they use wood for heating purposes that were $69 \%$ of forest villagers use both for cooking and heating purposes. This situation indicates the presence of pressure in forest villagers that consume wood for heating purposes. $7 \%$ of the subjects who received loans stated that they were pleased to have received ORKOY loans. In addition to it was determined that those who had received loans from ORKOY had received loans from dairy cattle. $61 \%$ of the subjects stated that they did not encounter any problems while receiving loans from ORKOY. $96 \%$ of the ORKOY loan recipients are men. Although this result suggests a perception that women are not interested in ORKOY projects, this situation stems from the Turkish family structure. However, it is women who will benefit the most from the solar water heating type project for social purposes.

\section{Hypothesis Results}

Analyzing the frequency distribution of demographic, socio-economic, and forest public relations characteristics in local forest villagers were determined by tables and percentage value tables. The results according to hypotheses are listed below. The data was 
percentage calculation and frequency analysis obtained from the surveys conducted in Gumushane. One sample t-test was used in SPSS statistical software. The obtained result was checked with the degree of freedom using $\mathrm{t}$ table and it was determined whether it was away from the normal distribution. The 3 hypotheses established in this section were analyzed by SPSS program One-Sample tTest.

Hypothesis 1: Does the solar system have an effect on the consumption of firewood in heating? $\mathrm{H}_{10}$ : The consumption of firewood did not change after the use of solar energy. $\mathrm{H}_{11}$ : The consumption of firewood changed after the use of solar energy. The forest villagers participating in the evaluation are used as a primary source of fuel for heating purposes by $92 \%$ of the woodcut from the forest. We find that the difference between the responses of the participants and the consumption of firewood in warming is the average (-0.4474). 95\% in the t-test in the hypothesis at the significance level, the lower and upper limits of the differences of the means are between -2.1350 and 1.2403.
(Table 2). The effect of the solar system on the consumption of firewood in heating was analyzed at a 5\% significance level (or 95\% confidence interval). When interpreting the values in table 1 seen in the SPSS analysis, $t$ value, df and significance (2-tailed) (two tailed / directional significance) values are examined. According to the test results, if the significance value is less than from $0.05 \%$ to $5 \%$ significance level, the $\mathrm{H}_{10}$ hypothesis can not be rejected. When we look at the table above, significance (2-tailed) value is $\mathrm{P}=$ 0.594 and is greater than 0.05 , and the $\mathrm{H}_{11}$ hypothesis can be rejected. In other words, after the use of solar energy, the consumption of firewood in house heating has not changed.

Also, when we look at the lower and upper limits of the differences of the means at the $95 \%$ significance level $(-2.1350 ; 1.2403)$, it is concluded that there is no significant difference between the two means since the interval includes the value " 0 " $\left(\mathrm{T}_{0,025 ; 69}\right.$ $=1,990$, established value $=-0.537)$. Therefore $(-1.990<-0.537<1.990)$.

Table 2. One sample t-test difference averages in heating (hypothesis 1)

\begin{tabular}{ccccccc}
\hline & & $\mathrm{N}$ & Average & \multicolumn{2}{c}{$\begin{array}{c}\text { Standard } \\
\text { Deviation }\end{array}$} & Standard Error Average \\
\hline Difference & & 70 & -0.4474 & 5.13440 & \\
\hline & Test value $=0$ & & & & & \\
\cline { 2 - 7 } & $\mathrm{t}$ & $\mathrm{df}$ & $\mathrm{P}$ value & $\begin{array}{c}\text { Average } \\
\text { Difference }\end{array}$ & \multicolumn{2}{c}{ Confidence Interval \%95 } \\
\hline Difference & -0.537 & 69 & 0.594 & -0.4474 & -2.1350 & $\max$ \\
\hline
\end{tabular}

Hypothesis 2: Does the solar energy heating system have an impact on the consumption of firewood in cooking? $\mathrm{H}_{20}$ : The consumption of firewood did not change after the use of solar energy. $\mathrm{H}_{21}$ : Consumption of firewood changed after use of solar energy. It was observed that $14 \%$ of wood and $80 \%$ LPG were used as the primary fuel for cooking purposes. $95 \%$ in the t-test in the hypothesis 2 at the significance level, the lower and upper limits of the differences of the means are between -2.3499 and 1.2816. Test results of hypothesis 2 is $\mathrm{T}_{0,025 ; 69}=1.990$ : 69 (degree of freedom is 69, our table value is $(-6.888) . \mathrm{H}_{20}$ can be rejected test values was between -6.888 and 1.990. Table 3 presents' one sample t-test difference averages in water heating (Table $3)$. 
Table 3. One sample t-test difference averages in cooking (hypothesis 2)

\begin{tabular}{|c|c|c|c|c|}
\hline & $\mathrm{N}$ & Average & $\begin{array}{c}\text { Standard } \\
\text { Deviation }\end{array}$ & Standard Error Average \\
\hline \multirow[t]{4}{*}{ Difference } & 70 & $-1,8158$ & 1,62506 & 0,26362 \\
\hline & \multicolumn{4}{|l|}{ Test Value $=0$} \\
\hline & \multirow[t]{2}{*}{$\mathrm{t} \quad \mathrm{df}$} & \multirow[t]{2}{*}{$P$ value } & \multirow{2}{*}{$\begin{array}{c}\text { Average } \\
\text { Difference }\end{array}$} & Confidence Interval $\% 95$ \\
\hline & & & & $\min \quad \max$ \\
\hline Difference & $-6,888$ & 0,000 & $-1,8158$ & $-2,3499$ \\
\hline
\end{tabular}

Hypothesis 3: Does the solar system have an effect on the consumption of firewood in water heating? $\mathrm{H}_{30}$ : The consumption of firewood did not change after the use of solar energy $\mathrm{H}_{31}$ : Consumption of firewood changed after the use of solar energy. As a result of this study, woodcut from the forest is used as a source of fuel in $71 \%$ of water heating. The difference between the participants in the consumption of firewood in water heating was calculated as the mean (-1.3421) (Table 4). Test result of hypothesis 3 is $\mathrm{T}_{0,025 ; 69}=1.990: 69$ (degree of freedom is 69 , our table value is $(-8.324) . \mathrm{H}_{30}$ can be rejected test values was between -8.324 and 1.990. Table 4 presents one sample t-test difference averages in water heating.

Table 4. One sample t-test difference averages in cooking (hypothesis 3)

\begin{tabular}{|c|c|c|c|c|}
\hline & $\mathrm{N}$ & Average & $\begin{array}{l}\text { Standard } \\
\text { Deviation }\end{array}$ & Standard Error Average \\
\hline \multirow[t]{4}{*}{ Difference } & 70 & -1.3421 & 0.99394 & 0.16124 \\
\hline & \multicolumn{4}{|l|}{ Test value $=0$} \\
\hline & \multirow[t]{2}{*}{$\mathrm{t} \quad \mathrm{df}$} & \multirow[t]{2}{*}{$\mathrm{P}$ value } & Average & Confidence Interval \%95 \\
\hline & & & Difference & $\min \quad \max$ \\
\hline Difference & -8.324 & 0.000 & -1.3421 & -1.0154 \\
\hline
\end{tabular}

$87 \%$ of the participants who received a loan stated that they were happy to have received an ORKOY loan. $61 \%$ of the respondents stated that they did not encounter any problems while ORKOY loan. 89\% of the subjects did not make a loan request from ORKOY before the ORKOY loan they received. Reasons for the rejection of ORKOY loans; for ORKOY loan not to be named in the draw, they had previously benefited from ORKOY credit, ORKOY had the opportunity to give credit to a limited number of villagers, and the bureaucratic procedures of the ORKOY lending process were excessive. The most frequently stated reason for rejection is that their names do not appear in the draw. Forest villagers think that drawing lots does not yield good results. $100 \%$ of the subjects using ORKOY projects agree that they increase their income albeit at different degrees. The resulting water-saving firewood for heating purposes is 54\%. The respondents stated that with this project, there was a $74 \%$ reduction in tube consumption,
$54 \%$ in firewood consumption and $16 \%$ in other consumption. The solar water heating type project has been expected to reduce forest villagers' use of wood and reduce their pressure on the forest. For this reason, it is seen that ORKOY has achieved the desired result from this project. $71 \%$ of the subjects stated that the project had no negative impact, while $29 \%$ stated that it required additional costs where according to the results obtained, the companies installing the solar energy system, the roofs of the houses, walls and so on damage. As can be seen, the implementation of this project has had a positive impact on the budget and forest ecosystems of the forest villagers.

\section{Conclusion}

Energy demand in Turkey, largely oil, are covered with primary energy sources such as natural gas and coal. Primary energy use is mostly imported from abroad and this energy dependency is at the level of 70\% (Bayar, 2014). 
Among the reasons for the degradation of these forest ecosystems has been a decrease in forest areas, the change of other land-use situations, mention grasslands and soil erosion. State attempts to rebuild these areas can be often failed. Because it can be achieved by the public acceptance of the defenses that absolutely condition the success of the reforestation work of the forest. When faced with this situation, a new approach based on awareness and appropriate solutions should be investigated for the conservation and development of natural resources with the understanding of social forestry. It is necessary to expand the use of more incomeincreasing and renewable energy sources among forest villagers. In order to prevent the occurrence of consequences that may adversely affect forest resources management; awareness-raising activities should be carried out on the economic, ecological, social, and environmental benefits provided by forests and their importance. It is necessary to raise awareness about the use of new technologies in all segments of society and especially with political decision-makers under the leadership of forestry organizations and non-governmental organizations related to forestry (Coşkun et al. 2016; Çakır et al., 2019; Alaoui, et al., 2020).

The General Directorate of Forestry has initiated different projects in order to obtain the highest efficiency and increase the forest area in terms of quality and quantity. Thus, efforts to reduce social pressure on forests for a significant increase in productive forests have put these projects into practice (Sivrikaya et al., 2011).

The primary reason for the use of these systems is the cheap, easy and fast way to meet the need of hot water almost every hour of the day. Such systems can easily meet a family's daily need for hot water with a minimum amount of sunbathing time. Although there is no significant difference between the solar heating systems designed and used in 1980 with the development of technology, some improvements have been made and annual production amounts have been increased. In some of the developed systems, the chemical substances in the sections absorbing the sun's rays have been changed and the way of making more use of solar energy has been opened. The cost of solar heating systems to forest villagers arises during the initial purchase and installation. Once the installation has been completed and started to be used, forest villagers can meet their clean and healthy hot water needs at no cost. The systems, which are recognized by the installation companies for a certain period of warranty, have a service life of 15-20 years. The biggest problem encountered in these systems is the explosion of boilers or honeycombs that are affected by frost events. When such a situation is encountered, an additional cost is incurred by replacing the parts that are often unusable. Although these costs intimidate the forest villagers, they can pay off in 2-3 years unless they are otherwise. As a result, it offers forest villagers savings in the following years. In order to expand the use of solar heating systems, forest villagers should be made aware of this issue. At the same time, the population in the forest villages is directly influential in this context as well as the age of the people living in the settlement. Even if all these developments are achieved, the old habits of forest villagers cannot be broken.

Although our country is in a good condition in terms of solar energy potential, unfortunately, this potential cannot be used effectively and widely. The use of solar energy in Turkey (except solar water heating systems) is generally known, is no promotion. Therefore, it cannot be engineering, consultancy and contracting companies and related industries that will provide services in this field non-develop. These systems, which have high initial investment costs, but do not require a large investment other than operating expenses due to the lack of fuel costs, are among the clean energy resources (Varinca, 2006).

It has concluded that the factors $\left(\mathrm{CO}_{2}\right.$ emissions) that we expect to have a negative impact on environmental degradation in $\mathrm{EU}$ countries cannot as expected, thanks to renewable energy and savings energy resources. It has shown that the increase in renewable energy consumption will decrease the amount of $\mathrm{CO}_{2}$ per capita at a statistically significant level by $1 \%$. This variable has occurred in the short term, due to technological progress and the increasing 
share of renewable sources in the energy mix of EU countries (Bhattacharyya, 2011: Zink and Geyer, 2017; Korhonen et al., 2018; Pham et al, 2020).

Solar heating systems provide financial benefits for water heating in homes. In addition to this gain, it has pioneered wood saving by reducing the excessive use of state dominated forests. Thanks to these projects, the damage to our forests was reduced and forest villagers were protected. The Forest Law No. 6831, which was enacted in 1956, offers great opportunities for development and change in forestry. It is planned to increase fertile forest areas through rehabilitation works. In this way, the amount of wood needed by people to meet the amount of firewood and wood, natural developing forest areas for other purposes, can be used more efficiently. It should be noted that forests are not an endless resource. This has enabled our forests to be managed better and more consciously. Not only solar heating systems but also stoves, fossil fuels, solar cells and, if possible, natural gas can be used to save fuel consumption. Thus, the existing firewood and solar energy can be utilized more. In addition, loss of heat energy in the house can be prevented by providing proper insulation in the houses. In this case, the amount of firewood to be used will be reduced. Thus, the effects of the ORKOY projects implemented on the demographic, socio-economic, relationship with forests, ORKOY practices and forest-public relations of the local forest villagers were determined. In order to avoid wasting wood, alternative energy sources such as solar energy, coal and electricity should be encouraged. In addition, thermally insulated house projects should be developed in accordance with local conditions and encouraged by the state, and studies should be conducted to increase the yields of forests with existing firewood sources such as village coppice plants. In the forest villages, not only solar heating systems but also solar batteries can be used to reduce fuel consumption. Thus, the existing firewood and solar energy can be utilized more. In addition, loss of heat energy in the house can be prevented by providing proper insulation in the houses. In this case, the amount of firewood to be used will be reduced.

\section{Ethics Committee Approval} N/A

\section{Peer-review}

Externally peer-reviewed.

\section{Author Contributions}

Conceptualization: G.Ç., $\quad$ S.A.T.; Investigation: G.Ç., S.A.T.; Material and Methodology: G.Ç., S.A.T.; Supervision: G.Ç., S.A.T.; Visualization: G.Ç., S.A.T.; Writing-Original Draft: G.Ç., S.A.T.; Writing-review \& Editing: G.Ç., S.A.T.; Other: G.C.., S.A.T. All authors have read and agreed to the published version of manuscript.

\section{Conflict of Interest}

The authors have no conflicts of interest to declare.

\section{Funding}

The authors declared that this study has received no financial support.

\section{Acknowledgements}

This study was prepared by Süleyman Aykut TONYALI under the supervisor of Professor Günay ÇAKIR in the Gumushane University Natural and Applied Science Institute Department of Forestry and Environment Science.

\section{References}

Altuntop, N. \& Erdemir, D. (2013). Dünyada ve Türkiye'de güneş enerjisi ile ilgili gelişmeler, Mühendis ve Makina, 54(639), 69-77.

Alaoui, A., Laaribya, S., Ayan, S. (2020). Forest Cover with the effect of anthropic pressure (The Case Study of Sehoul Cork-Oak Forest in Morocco, North Atlantic). Kastamonu University Journal of Forestry Faculty. 20(1), 62-73.

Bhattacharyya, C.S. (2011). Energy economics: Concepts, issues, markets and governance. Springer. ISBN: 978-0-85729-267-4. https://doi.org/10.1007/978-0-85729-268-1. UK. XXVI-721.

Bayar, Y. (2014). Türkiye'de birincil enerji kullanimi ve ekonomik büyüme. Atatürk Üniversitesi İktisadi ve Idari Bilimler Dergisi, 28(2), 253-268.

Coşkun A.K., Öztürk, A. \& Türker M. (2016). Türkiye'de hükümetlerin orman kaynakları yönetimi ve işletmeciliğine yönelik bazı 
uygulamalarının irdelenmesi (1961-2012 Dönemi). Kastamonu University Journal of Forestry Faculty 16(1), 96-110.

Çakır, G. (2013). Ecological and economical advantages of solar water heating systems used by forest villagers in Gumushane, Turkey. Journal of Food, Agriculture and Environment, 11(3\&4), 1791-1793.

Çakır, G., Kaya, L.G., Yücedağ, C. \& Bayram, S. (2019). Determination of the effects of Alucra Forest planning unit's population dynamics on land use changes. Kastamonu University Journal of Forestry Faculty. 19(1), 35-46. Doi:10.17475/kastorman.543415.

Çoban, C. (1997). ORKOY sorunları, nedenleri, çözüm önerileri ve katılımcı yönetim. Orman ve Av Dergisi, 73(4), 30-32.

Doğan, A.R. (2012). Güneş enerjisi destekli alternatif isıtma sistemlerinin enerji ve ekonomi yönünden karşılaştırılması. Yüksek Lisans Tezi, Gazi üniversitesi Fen Bilimleri Enstitüsü, ANKARA.

DPT, (2006). State Planning Organization. V Beş yıllık kalkınma planı ormancılık Ö.İ.K. raporu. DPT Yayın No: 310, Ankara, Turkey.

EIGM, (2014). General Directorate of Electrical Power Resources Survey and Development Administration. http://www.eie.gov.tr).

GDF, (2018), General Directorate Forestry, Forest and forest villages, Annual reports, Ankara.

GGv, (2014). Gumushane Governorship. Geographic Information of Gumushane Province. (www.gumushane.gov.tr)

IRENA, (2020). Energy Profile Turkey, International Renewable Energy Agency, Reports, 2020.

İstanbullu, T. (1978). Türkiye' de yakıt ve özellikle yakacak odun sorunu üzerine araştırmalar, İ.Ü. Yayın No. 2405, O.F. Yayın No: 251, Çelikcilt Matbaası.

Korhonen, J., Honkasalo, A. \& Seppälä, J., (2018). Circular economy: the concept and its limitations. Ecological Economics. 143, 37-46. https://doi.org/10.1016/j.ecolecon.2017.06.04 1.

MGM, (2014). Meteorological values in Gumushane, Turkish Meteorological Institute, (https://www.mgm.gov.tr/veridegerlendir me/il-ve-ilceler-istatistik. Aspx), press Turkish).

Odum, T.H. \& Odum, C.E., (2006). The prosperous way down. Energy. 31, 21-32.

ORKOY, http://www.orkoy.gov.tr/ORKOY/AnaSay $\mathrm{fa} /$ gunesenerjilisuisitmasistemleri kredisi. aspx?sflang=tr, 20 March 2014.

Pham, N.M., Huynh T.L.D. \& Nasir M.A., (2020). Environmental consequences of population, affluence and technological progress for European Countries: A Malthusian view, Journal of Environmental Management. 260, 110-143. https://doi.org/10.1016/j.jenvman.2020.11014 3.

Sivrikaya, F., Çakır, G. \& Akay, A.E., (2011). Foctors of land use/cover change: A case study from Turkey. Scientific Research and Essays, 6(17), $3684-3696$.

Tonyalı, S.A. (2019). Evaluation of socioeconomic conditions by using solar water heating systems in Gumushane Forest Villagers. Gumushane University Graduate School of Natural and Applied Sciences Dept. of Forestry and Environmental Sciences. Master of Science Thesis, Gumushane.

TUIK, (2014). Turkish Statistical Institute, Demographic and social indicators in Gumushane, http://www.tuik.gov.tr/Start.do.

Türker M.F. \& Toksoy D. (1992). Devlet ormanlarından odun hammaddesinin yakacak odun amaciyla tüketilmesi probleminin çözüm yollar1, Ekoloji ve Çevre Dergisi, 1, 5-8.

Varınca, K.B. \& Gönüllü M.T. (2006). Türkiye'de güneş enerjisi potansiyeli ve bu potansiyelin kullanım derecesi, yöntemi ve yaygınlığ üzerine bir araştırma, UGHEK'2006: I. Ulusal Güneş Ve Hidrojen Enerjisi Kongresi Proceeding Book, 21-23 Haziran 2006, 270275. Eskişehir.

Zink, T. \& Geyer, R., (2017). Circular economy rebound. Journal of Industrial Ecology. 21(3), 593-602. https://doi.org/10.1111/jiec.12545. 